\title{
Article \\ Capsule Independent Antimicrobial Activity Induced by Nanochitosan against Streptococcus pneumoniae
}

\author{
Fulwah Y. Alqahtani ${ }^{1, *}$, Fadilah S. Aleanizy ${ }^{1}$, Eram El Tahir ${ }^{1}{ }^{\mathbb{D}}$, Hessa Alowais ${ }^{1}$, Assalh Binkelaib ${ }^{1}$, \\ Bdour Alwathlan ${ }^{1}$, Asmaa Al-Bdrawy ${ }^{1}$, Anders P. Håkansson ${ }^{2}$ (D) and Ibrahim Alsarra ${ }^{1}$ (D) \\ 1 Department of Pharmaceutics, College of Pharmacy, King Saud University, Riyadh 11495, Saudi Arabia; \\ faleanizy@ksu.edu.sa (F.S.A.); ekeltahir@ksu.edu.sa (E.E.T.); ihessa.aziz@gmail.com (H.A.); \\ a.binkeliab@gmail.com (A.B.); bdour.z.alwathllan@gmail.com (B.A.); asmaabdrawy2@gmail.com (A.A.-B.); \\ ialsarra@ksu.edu.sa (I.A.) \\ 2 Department of Translational Medicine, Division of Experimental Infection Medicine, Lund University, \\ SE-21428 Malmö, Sweden; anders_p.hakansson@med.lu.se \\ * Correspondence: fyalqahtani@ksu.edu.sa
}

\section{check for} updates

Citation: Alqahtani, F.Y.; Aleanizy, F.S.; El Tahir, E.; Alowais, H.; Binkelaib, A.; Alwathlan, B.; Al-Bdrawy, A.; Håkansson, A.P.; Alsarra, I. Capsule Independent Antimicrobial Activity Induced by Nanochitosan against Streptococcus pneumoniae. Polymers 2021, 13, 2924 https://doi.org/10.3390/ polym 13172924

Academic Editor: Luminita Marin

Received: 12 August 2021

Accepted: 27 August 2021

Published: 30 August 2021

Publisher's Note: MDPI stays neutral with regard to jurisdictional claims in published maps and institutional affiliations.

Copyright: (c) 2021 by the authors. Licensee MDPI, Basel, Switzerland. This article is an open access article distributed under the terms and conditions of the Creative Commons Attribution (CC BY) license (https:/ / creativecommons.org/licenses/by/ $4.0 /)$.

\begin{abstract}
Background: Streptococcus pneumoniae remains a major cause of community-acquired pneumonia, meningitis, and other diseases, contributing significantly to high morbidity and mortality worldwide. Although it responds to antibiotics, their use is becoming limited due to the rise in antibiotic resistance, which necessitates the development of new therapeutics. Nanotechnology is used to counteract antimicrobial resistance. In this regard, polymeric nanoparticles (NPs) made of natural, biodegradable, biocompatible, and cationic polymers such as Chitosan (CNPs) exhibit wide-spectrum antimicrobial activity. Therefore, this study aimed to prepare CNPs, characterize their physiochemical characteristics: particle size (PZ), polydispersity index (PDI), and zeta potential (ZP), and investigate their antimicrobial activity against Streptococcus pneumoniae TIGR4 (virulent serotype 4 ) and its capsular mutant ( $\Delta$ cps). Methods: CNPs were prepared at $1,2.5$, and $5 \mathrm{mg} / \mathrm{mL}$ concentrations using the ion gelation method. Then, PZ, PDI, and ZP were characterized using a Zetasizer. Transmission electron microscopy (TEM) was used to visualize the CNP's morphology. Broth and agar dilution methods were used to assess their antimicrobial activity. Cytotoxicity of prepared NPs on A549 cells and their effect on pneumococcal hemolysis were also investigated. Results: Spherical CNPs were produced with PZ ranging from $133.3 \mathrm{~nm} \pm 0.57$ to $423 \mathrm{~nm} \pm 12.93$ PDI $<0.35$, and ZP from $19 \pm 0.115$ to $27 \pm 0.819$. The prepared CNPs exhibited antibacterial activity against TIGR4 and its capsule mutant with a minimum inhibitory concentration (MIC90) of 0.5 to $2.5 \mathrm{mg} / \mathrm{mL}$ in a non-acidic environment. The hemolysis assay results revealed that CNPs reduced bacterial hemolysis in a concentration-dependent manner. Their mammalian cytotoxicity results indicated that CNPs formed from low concentrations of Chitosan (Cs) were cytocompatible. Conclusion: Nanochitosan particles showed anti-pneumococcal activity regardless of the presence of capsules. They resulted in a concentration-dependent reduction in bacterial hemolysis and were cytocompatible at a lower concentration of Cs. These findings highlight the potential of CNPs in the treatment of pneumococcal diseases.
\end{abstract}

Keywords: Streptococcus pneumoniae; chitosan nanoparticles; nanochitosan; antimicrobial; hemolysis; capsule

\section{Introduction}

Streptococcus pneumoniae (the pneumococcus) is a gram-positive bacterium and a major human pathogen. It causes a spectrum of diseases, including bacterial otitis media, pneumonia, meningitis, and septicemia, and contributes to high morbidity and mortality globally, particularly in young children, the elderly, and immunocompromised individuals [1]. There are effective antibiotics used for the treatment of pneumococcal infections; however, their increased utilization and incomplete treatment schemes have led to the 
emergence of multidrug-resistant pneumococcal strains that spread worldwide [2]. According to a recent report from the World Health Organization (WHO) published in 2014 regarding global antibiotic resistance, pneumococcus was classified as one of nine bacteria of international concern [3]. Therefore, alternative antimicrobial strategies to combat S. pneumoniae infection are direly needed.

The use of nanotechnology, particularly polymeric nanoparticles (PNPs), has emerged in recent years as an alternative tool to develop antimicrobial therapeutics [4,5]. In this regard, NPs made from natural polymers such as Chitosan (Cs) have received much attention lately. This is owed to Cs biocompatibility, biodegradability, non-toxicity, and broad-spectrum antimicrobial activity against fungi, gram-positive, and gram-negative bacteria [6-8]. Chitosan is a polymer of a linear polysaccharide constituting of $\beta-(1-4)$ linked $\mathrm{N}$-acetyl-D-glucosamine, which is generated from the partial or total deacetylation of chitin [6,9]. A recent recommendation from the United States Food and Drug Administration (USFDA) has recognized shrimp-derived Chitosan as Generally Recognized As Safe (GRAS) for general use in foods [10]. The exhibited antimicrobial properties of Cs are explained by variable mechanisms; nevertheless, the exact mechanism still needs to be elucidated $[6,7,11]$. The most commonly suggested mechanism is based on the electrostatic attraction between $\mathrm{Cs}$ and the anionic surface of bacteria leading to changes in cell membrane permeability and leakage of intracellular bacterial components and consequently cell death $[6,7,11]$. Nonetheless, the observed antimicrobial efficacy of Cs is influenced by many factors, including molecular weight, degree of deacetylation, and positive charge content $[6,7,11]$.

Several reports have shown a higher antimicrobial activity of nanoparticles obtained from Cs (CNPs) against a wide range of pathogens than the activity of Cs itself [12-18]. This superior activity could be attributed to the small size and quantum size effect of CNPs. Considering the global rise in pneumococcal antimicrobial resistance and the potential of CNPs to act as antimicrobial agents, this study was therefore conducted to formulate nanochitosan, investigate their physicochemical properties, and evaluate their potential antimicrobial activity against Streptococcus pneumoniae.

\section{Materials and Methods}

\subsection{Materials}

Low molecular weight Chitosan (LMW, 50-190 kDa, Degree of deacetylation; $\mathrm{DD}=75-85 \%)$, tripolyphosphate (TPP), and acetic acid were purchased from SigmaAldrich (St. Louis, MO, USA). Blood agar plates (BA) and Todd Hewitt broth supplemented with $0.5 \%$ yeast extract (THYB) were obtained from Merck (Darmstadt, Germany). All solvents and chemicals were of analytical grade. Dulbecco's modified Eagle's medium (DMEM), fetal bovine serum (FBS), and antibiotic-antimycotic solution were obtained from Gibco (Grand Island, NY, USA).

\subsection{Preparation of CNPS}

As described previously, with slight adjustment [16,19], CNPs were formulated utilizing the ionic gelation method. Cs solutions were prepared at concentrations of 1,2.5, and $5 \mathrm{mg} / \mathrm{mL}$ in $1 \% v / v$ acetic acid. Then, $1 \mathrm{~mL}$ of $0.1 \% w / v$ TPP solution was added to 4 $\mathrm{mL}$ of Cs under continuous magnetic stirring at $800 \mathrm{rpm}$ for $1 \mathrm{~h}$ to form the nanoparticles. Following centrifugation at $10,000 \times \mathrm{g}$ for $20 \mathrm{~min}$, recovered NPs were washed twice by centrifugation and reconstituted in distilled water and stored at $4{ }^{\circ} \mathrm{C}$ for NP characterization and further experiments.

\subsection{Characterization of Formulated NPS}

The particle size, zeta potential, and polydispersity index (PDI) were determined using dynamic light scattering with a Zetasizer (Particle Sizing Systems, Port Richey, FL, USA). All measurements were carried out in triplicate and reported as the mean \pm standard 
deviation (SD). The NP morphology was examined using the Tecnai transmission electron microscope (TEM) (Hillsboro, OR, USA).

\subsection{Stability Studies}

The stability of prepared CNPs was evaluated at different possible proper storage temperatures $\left(25^{\circ} \mathrm{C}, 4{ }^{\circ} \mathrm{C}\right.$, and $\left.-30^{\circ} \mathrm{C}\right)$ for 3 months. At predetermined time points $(0,40$, and 80 days), samples were tested physically and characterized as a function of particle size $(\mathrm{nm})$, polydispersity index, and zeta potential $(\mathrm{mV})$.

\subsection{Bacterial Strains and Growth Conditions}

The pneumococcal strains and mutants used in this study are presented in Table 1. The bacteria were cultured on blood agar plates (BA) overnight or in THYB at $37^{\circ} \mathrm{C}$ in $5 \%$ $\mathrm{CO}_{2}$ and used in the antimicrobial testing.

Table 1. Pneumococcal strains used in the current study.

\begin{tabular}{ccc}
\hline S. pneumonia Strains & Description & References \\
\hline TIGR4 & S. pneumoniae serotype 4 clinical isolate & {$[20]$} \\
\hline TIGR4- $\Delta \mathrm{cps}$ & Capsule-free TIGR4, Erm ${ }^{\mathrm{R}}$ & {$[21]$} \\
\hline
\end{tabular}

\subsection{Antimicrobial Assay}

In this study, broth microdilution assays were used to determine the minimal inhibitory concentration of 90 ( $\mathrm{MIC}_{90}$ ) of the CNPs according to the Clinical and Laboratory Standard Institute (CLSI) protocols and as described previously $[16,18,22]$. The CNPs were diluted in Todd Hewitt broth (THYB) at twofold serial dilutions in standard Bioscreen C 100-well microtiter plates (Labsystems Oy, Helsinki, Finland). For inoculum preparation, all of the bacterial cell suspensions were first adjusted to McFarland $0.5(1-2 \times 108 \mathrm{CFU} / \mathrm{mL})$. The suspension was further diluted to provide a final inoculum density of $5 \times 105 \mathrm{CFU} / \mathrm{mL}$ in the wells of the microdilution plates. The plates were incubated for $7.5 \mathrm{~h}$ at $37^{\circ} \mathrm{C}$ and $5 \%$ $\mathrm{CO}_{2}$, and the optical density (OD) of the bacterial growth was recorded every $15 \mathrm{~min}$ at 600 $\mathrm{nm}$, and the MIC90 was calculated. The OD reading of each concentration of tested NPs and THYB medium alone were subtracted from the OD of the wells inoculated with bacteria to eliminate background. The MIC90 was defined as the minimal inhibitory concentration of the CNPs that reduced bacterial growth by $90 \%$.

For the killing assay, bacteria were diluted to $9 \times 106 \mathrm{CFU} / \mathrm{mL}$ in THYB in the presence of CNPs at $37^{\circ} \mathrm{C}$ for $5 \mathrm{~h}$. After incubation, bacteria were serially diluted and plated on BA and grown at $37^{\circ} \mathrm{C}$ and $5 \% \mathrm{CO}_{2}$ overnight, after which viable colonies were quantified. The concentrations were presented as $\mathrm{CFUs} / \mathrm{mL}$.

\subsection{Hemolytic Activity Assay}

Hemolytic activity was assayed as reported previously with minor modifications [23]. Overnight cultures of pneumococcal strains were sub-cultured in THYB until reaching an OD600 of 0.5. The culture was then diluted to an OD600 of 0.09 and co-incubated with serially diluted CNPs for $5 \mathrm{~h}$. After incubation, the bacteria were pelleted by centrifugation at 12,000 rpm for $5 \mathrm{~min}(\mathrm{~min})$, and supernatant from each sample was collected and filtered through a $0.22 \mu \mathrm{m}$ syringe filter (Merck Millipore, Burlington, MA, USA).

A blood sample was collected from a healthy volunteer with immediate transfer to an anticoagulant citrate tube, centrifuged at $500 \times g$ for $5 \mathrm{~min}$ in a $15 \mathrm{~mL}$ tube, and the supernatant was discarded and replaced with phosphate-buffered saline (PBS) for platelet removal. This step was repeated twice to obtain purified erythrocytes in the pellet, and the pellet was resuspended in a final volume of $1.5 \mathrm{~mL}$ PBS. For hemolytic activity assay, $675 \mu \mathrm{L}$ of THYB was mixed with $300 \mu \mathrm{L}$ of bacterial supernatant and $25 \mu \mathrm{L}$ of purified erythrocyte suspension and incubated at $37^{\circ} \mathrm{C}$ for $30 \mathrm{~min}$. Freshly prepared $0.1 \%$ Triton X-100 was used as a positive control (100\% hemolysis), and PBS was used as negative control $(0 \%$ 
hemolysis). The mixture was centrifuged at $10,000 \times g$ for $1 \mathrm{~min}$, and supernatants were collected and transferred to a 96-well plate, and absorbance of each sample was measured for hemoglobin content (at $590 \mathrm{~nm}$ ) in triplicate using an ELISA plate reader.

\subsection{Cytotoxicity Assay}

The cytotoxicity of the CNPs was investigated using alamarBlue as previously described [24]. Briefly, A549 cells (Human lung adenocarcinoma cell line CCL 185, ATCC) were seeded in 24-well plates in DMEM media supplemented with 10\% FBS and 1\% antibiotic-antimycotic solution overnight, until $70 \%$ to $90 \%$ confluency had been reached. The cells were then treated with the CNPs $(0.016-2.5 \mathrm{mg} / \mathrm{mL}$, for 24 and $48 \mathrm{~h}$. After experimental treatment, the cell media was discarded and replaced with fresh media containing $10 \%$ alamarBlue solution, and the cells were incubated for $2-4 \mathrm{~h}$ at $37^{\circ} \mathrm{C}, 5 \% \mathrm{CO}_{2}$. Fluorescence was recorded using $550 \mathrm{~nm}$ excitation and $590 \mathrm{~nm}$ emission wavelengths in a SpectraMax M5 fluorometer (Molecular Devices, CA, USA). The viability of treated cells was expressed as a ratio of non-treated cells after subtracting the signal from media alone from both samples as follows:

Cell Viability $(\%)=($ Fluorescence of cells treated with CNPs) $/$ (Fluorescence of cells non treated) $\times 100$

\subsection{Statistical Analysis}

Data were presented as the mean \pm standard deviation (SD). Analysis of the data was performed using GraphPad Prism version 8.0.0 for Mac OS (GraphPad Software, Inc, CA, USA). Student's $t$-test and ANOVA tests were used when appropriate. A $p$-value of $<0.05$ was considered significant.

\section{Results}

\subsection{Characterization of Nanochitosan}

In the present study, CNPs were successfully obtained adopting the ion gelation method as reported by former studies [16,19], which is based on crosslinking between cationic Cs and anionic TPP. As shown in Table 2, the dynamic light scattering results demonstrated average particle sizes of 133.3, 177, and $423 \mathrm{~nm}$ for CNPs prepared from Cs solution with concentrations of $1 \mathrm{mg} / \mathrm{mL}, 2.5 \mathrm{mg} / \mathrm{mL}$, and $5 \mathrm{mg} / \mathrm{mL}$, respectively. The results revealed that increasing Cs concentration led to a significant increase in the particle size and $\zeta$-potential of the synthesized NPs ( $p<0.05$, Table 2$)$. In this respect, NPs formulated from Cs solution of concentration $1 \mathrm{mg} / \mathrm{mL}(\mathrm{CNPs} 1 \mathrm{mg} / \mathrm{mL})$ displayed the smallest particle size $(133.3 \mathrm{~nm} \pm 0.57)$ and $\zeta$-potential $(17 \mathrm{mV} \pm 0.115)$.

Table 2. Physicochemical characteristics of formulated CNPs.

\begin{tabular}{cccc}
\hline Formulation & Size $(\mathbf{n m} \pm \mathbf{S D})$ & PDI \pm SD & $\zeta$-Potential $(\mathbf{m V} \pm \mathbf{S D})$ \\
\hline $\mathrm{CNPs}_{1} \mathrm{mg} / \mathrm{ml}$ & $133.3 \pm 0.57$ & $0.159 \pm 0.006$ & $19 \pm 0.115$ \\
$\mathrm{CNPs}_{2.5 \mathrm{mg} / \mathrm{ml}}$ & $177 \pm 2.85$ & $0.235 \pm 0.011$ & $24.7 \pm 1.06$ \\
$\mathrm{CNPs}_{5} \mathrm{mg} / \mathrm{ml}$ & $423 \pm 12.93$ & $0.281 \pm 0.014$ & $27 \pm 0.819$ \\
\hline
\end{tabular}

Consequently, the largest particle size and $\zeta$-potential were obtained with CNPs prepared from $5 \mathrm{mg} / \mathrm{mL}$ Cs solution $\left(\mathrm{CNPs}_{5} \mathrm{mg} / \mathrm{mL}\right)$, which provided particles of sizes $423 \mathrm{~nm} \pm 12.93$ and $\zeta$-potential of $27 \mathrm{mV} \pm 0.819$, respectively. The PDI results featured in Table 2 indicated high homogeneity of prepared NPs, as their PDI values were $\leq 0.281$ (Table 2). The graphs for the distribution of particle size of formulated CNPs are presented in Figure 1. As seen from TEM images in Figure 2, the NPs were spherical in shape. 
A

Size distribution by intensity $\left(\mathrm{CNP}_{1 \mathrm{mg} / \mathrm{ml}}\right)$

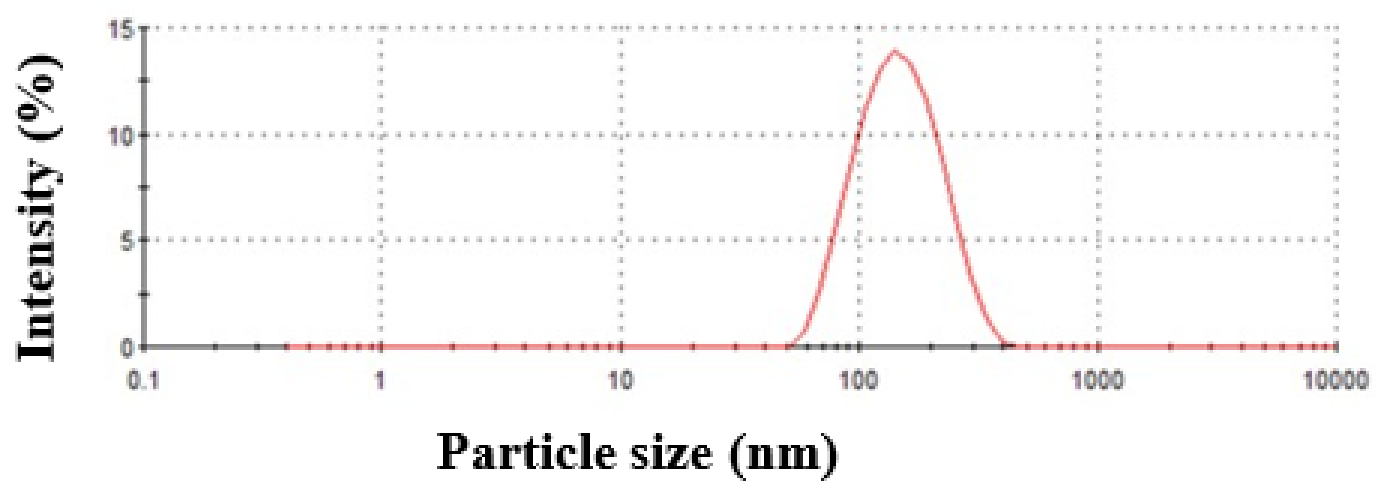

B

Size distribution by intensity $\left(\mathrm{CNP}_{2.5} \mathrm{mg} / \mathrm{ml}\right)$

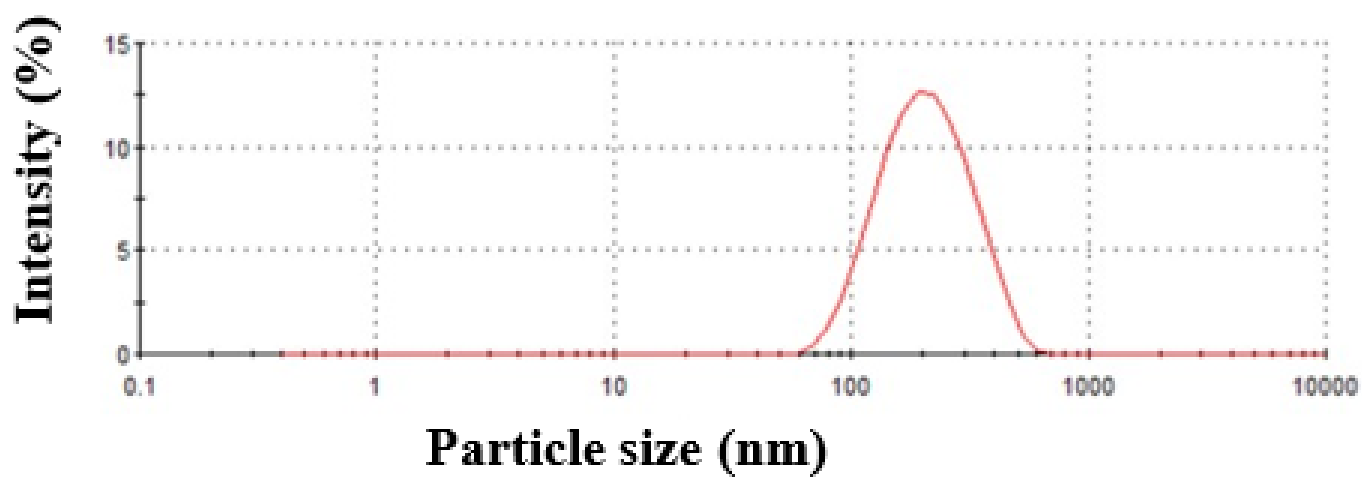

C

Size distribution by inten sity (CNPs $5 \mathrm{mg} / \mathrm{ml})$

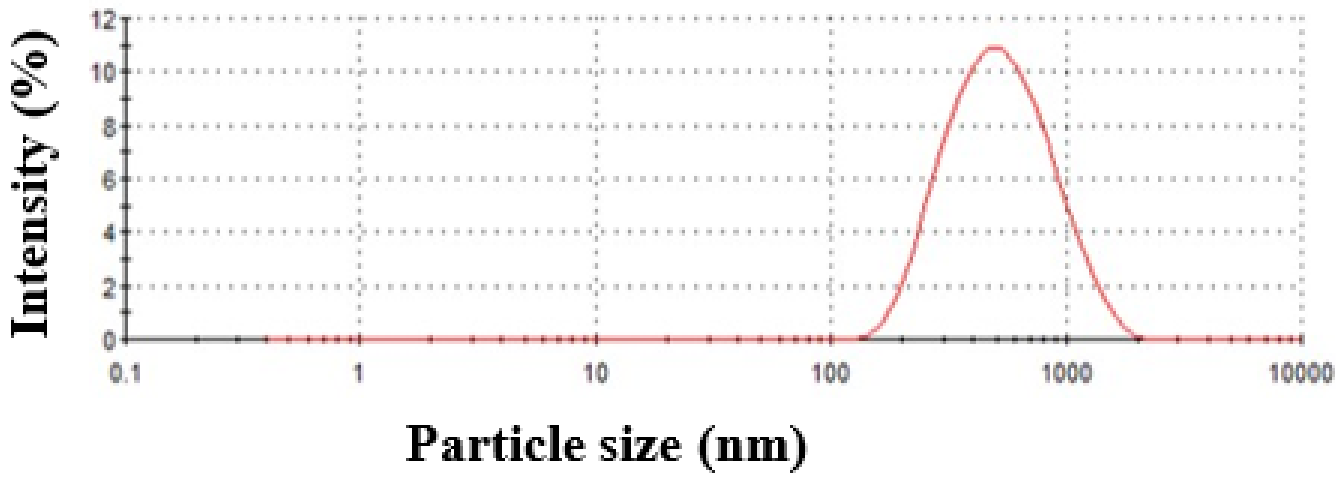

Figure 1. DLS spectra on of hydrodynamic size distribution of synthesized NPs. 
CNPsl mg/ml

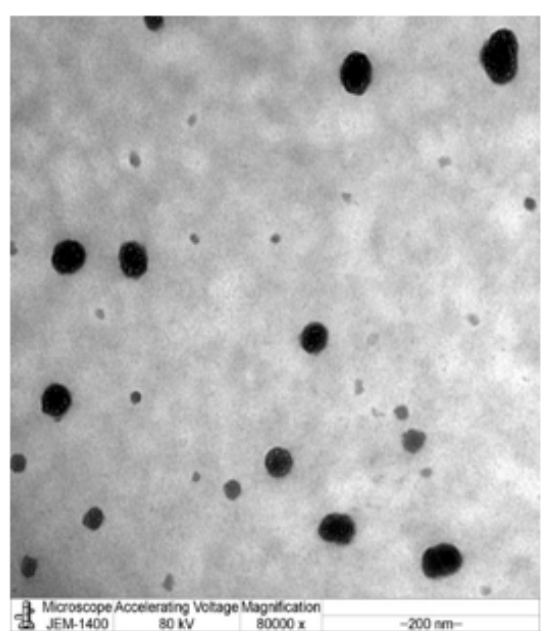

$\mathrm{CNPs}_{2.5 \mathrm{mg} / \mathrm{ml}}$

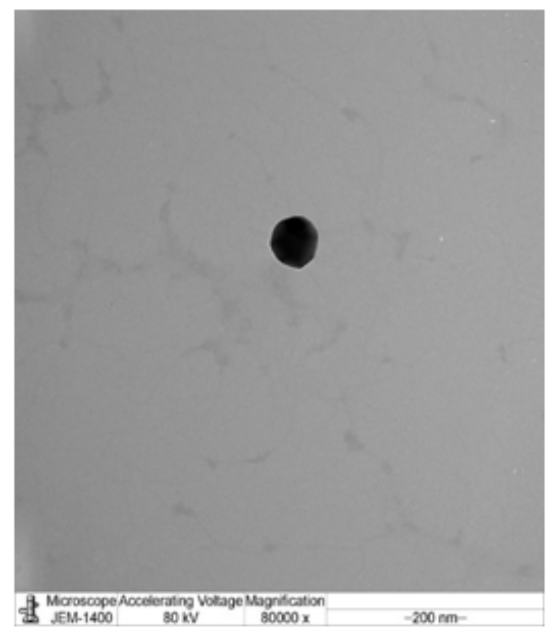

CNPs5 mg/ml

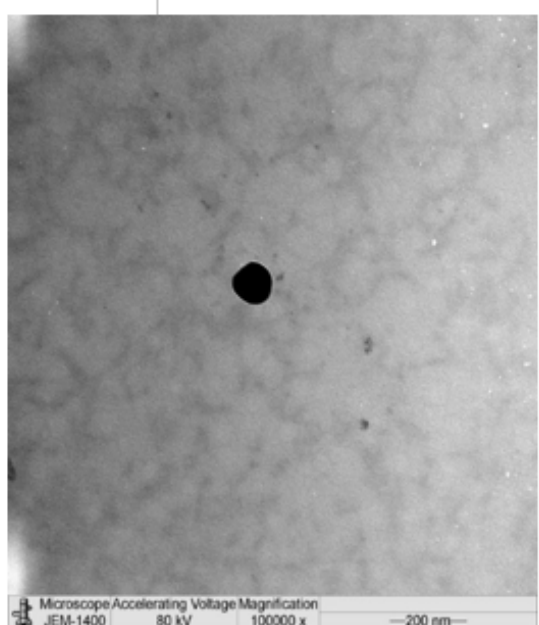

Figure 2. TEM images of formulated CNPs.

\subsection{NPs Stability under Variable Storage Condition}

As shown in Figure 3, no significant change in the particle size, PDI, and $\zeta$-potential of CNPs was observed when stored at $4{ }^{\circ} \mathrm{C}$ for different time intervals as compared with fresh formulations. In contrast, storing NPs at $-30{ }^{\circ} \mathrm{C}$ increased particle size significantly with an increase in storage intervals. Also, the PDI and $\zeta$-potential of CNPs kept at $-30{ }^{\circ} \mathrm{C}$ fluctuated markedly when compared with freshly prepared NPs (Figure 3A-C).
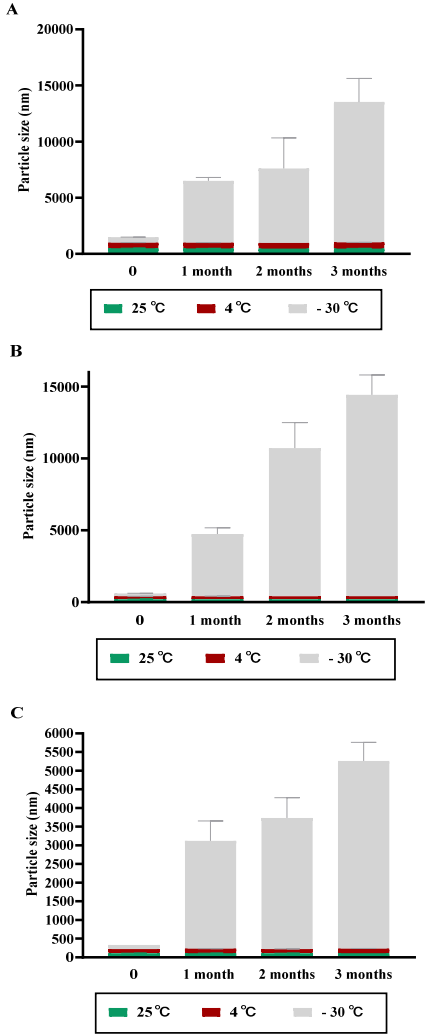
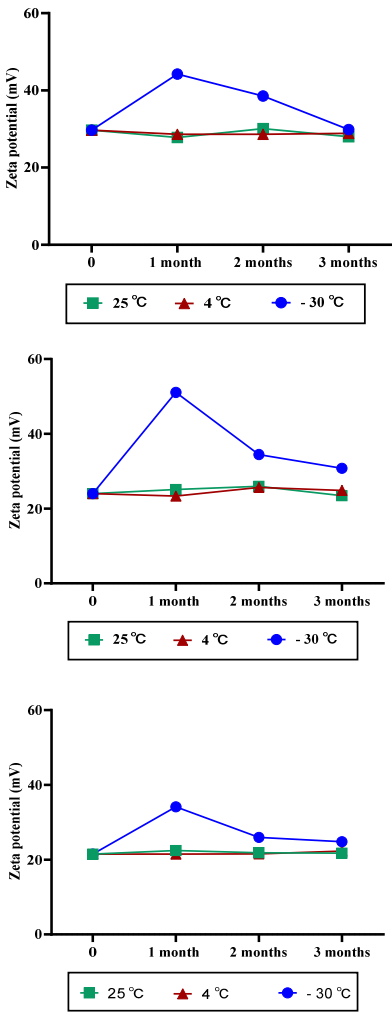
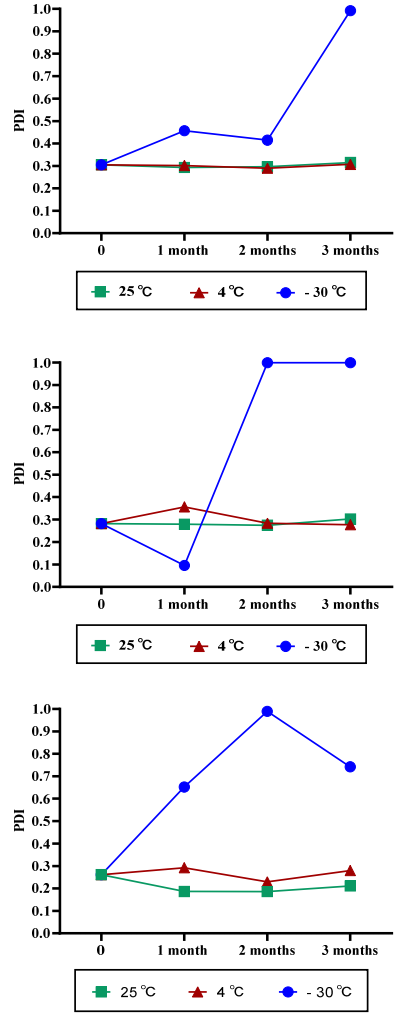

Figure 3. Characterization of CNPs at different time and storage conditions. Influence of different temperatures at different time points on the particle size, PDI, and $\zeta$-potential of $\mathrm{CNPs}_{5} \mathrm{mg} / \mathrm{mL}(\mathbf{A})$, $\mathrm{CNPs}_{2.5 \mathrm{mg} / \mathrm{mL}}(\mathbf{B})$ and $\mathrm{CNPs}_{1} \mathrm{mg} / \mathrm{mL}(\mathbf{C})$ were evaluated. The data is presented as the mean $\pm \mathrm{SD}$ of triplicate experiments. 


\subsection{Antimicrobial Activity of CNPs}

The antimicrobial activity of prepared NPs was next assessed against S. pneumoniae strain TIGR4 and its capsule-negative mutant (TIGR4- $\Delta$ cps.) using the broth dilution method. Initially, we tried to culture the pneumococcal strains at $\mathrm{pH}=5.5$, in which $\mathrm{Cs}$ is known to be protonated; however, bacteria did not grow under these conditions. Therefore, the experiment was performed at neutral $\mathrm{pH}$. The optical density of the bacteria cultured in the presence of CNPs was subtracted from the optical density of the formulations alone. Growth curve results showed that although growth-inhibitory activity was observed at lower concentrations, the $\mathrm{MIC}_{90}$ was obtained at $0.5 \mathrm{mg} / \mathrm{mL}, 1.25 \mathrm{mg} / \mathrm{mL}$, and $2.5 \mathrm{mg} / \mathrm{mL}$ for $\mathrm{CNPs}_{1 \mathrm{mg}} / \mathrm{mL}, \mathrm{CNPs}_{2.5} \mathrm{mg} / \mathrm{mL}$, and $\mathrm{CNPs}_{5} \mathrm{mg} / \mathrm{mL}$, respectively (Figure 4). The antibacterial effect of CNPs was not affected by the presence or absence of pneumococcal capsular polysaccharides (Figure 4).

\section{TIGR4}
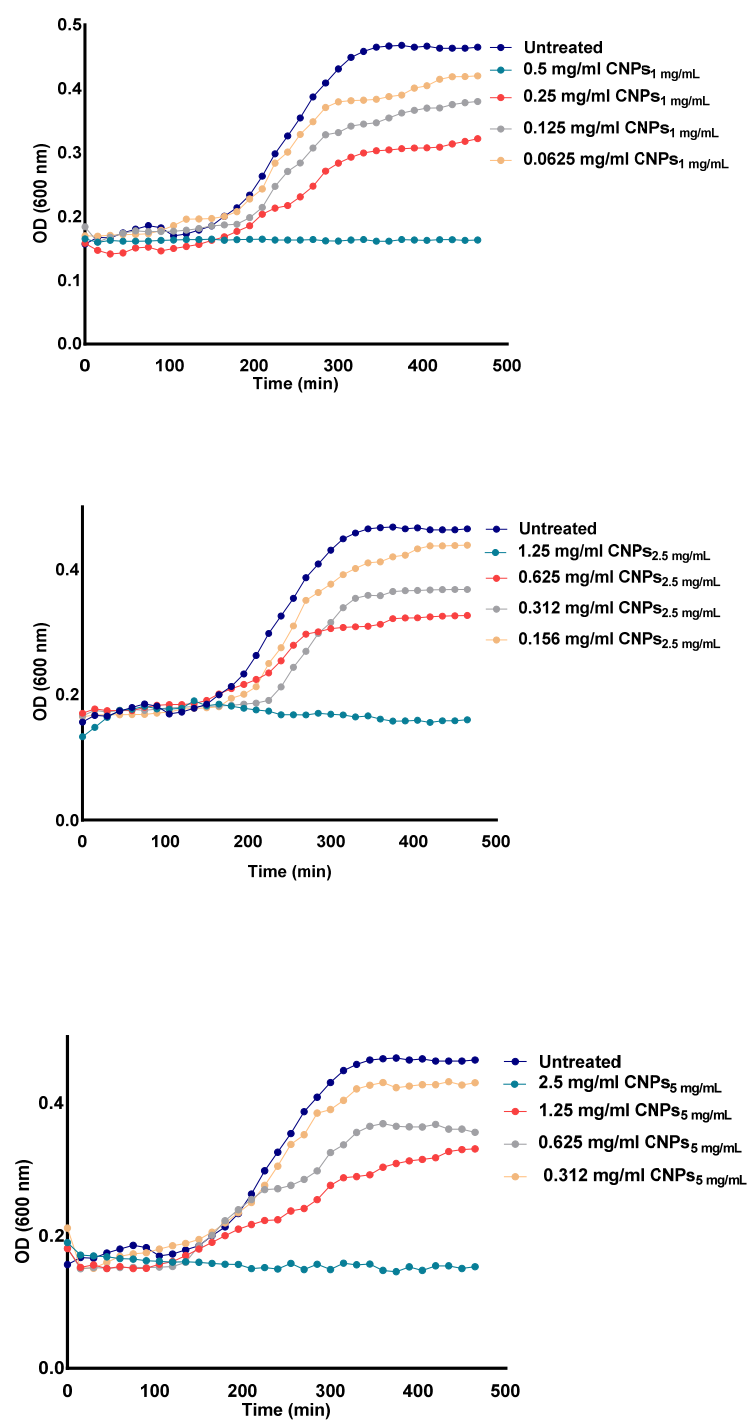

TIGR4- $\Delta$ cps
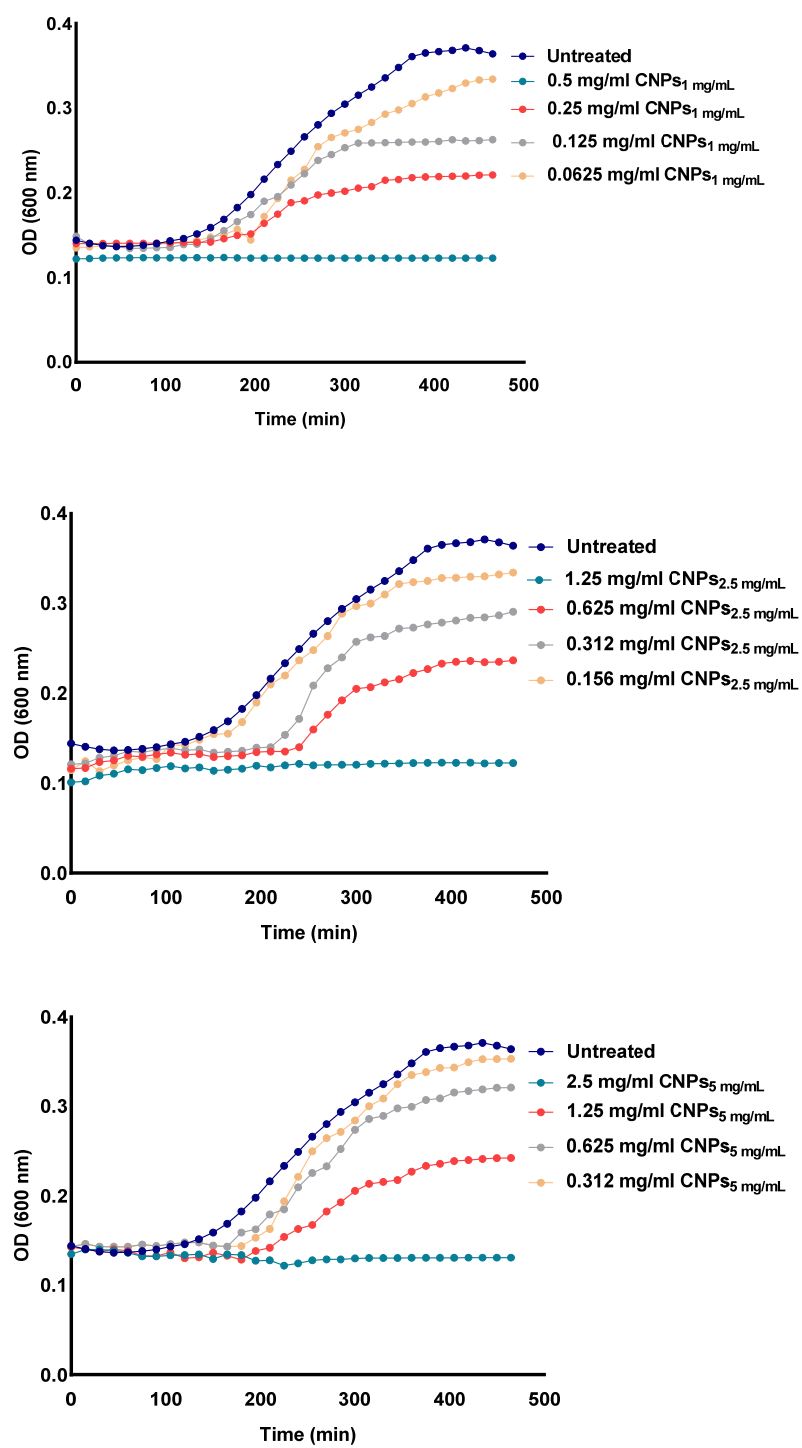

Figure 4. Growth curve of pneumococcal strains in the presence of CNPs. S. pneumoniae TIGR4 and TIGR4 $\Delta$ cps were cultured in THYB medium containing different concentrations of CNPs $1 \mathrm{mg} / \mathrm{mL}, \mathrm{CNPs}_{2.5 \mathrm{mg} / \mathrm{mL}}$, and CNPs $5 \mathrm{mg} / \mathrm{mL}$. Reduction in bacterial growth in the presence of CNPs was observed. The experiment was performed in triplicate. The data show one representative experiment. 
At higher concentrations of the formulations, the turbidity of the formulations in the media masked the turbidity resulting from bacterial growth; thus, a direct bactericidal assay was further conducted (Figure 5). As demonstrated in Figure 5, a dose-dependent reduction in bacterial viability was observed for the first four dilutions of each formula tested. Of note, the $\mathrm{pH}$ of the medium at first dilution in broth was approximately six.

\section{TIGR4}
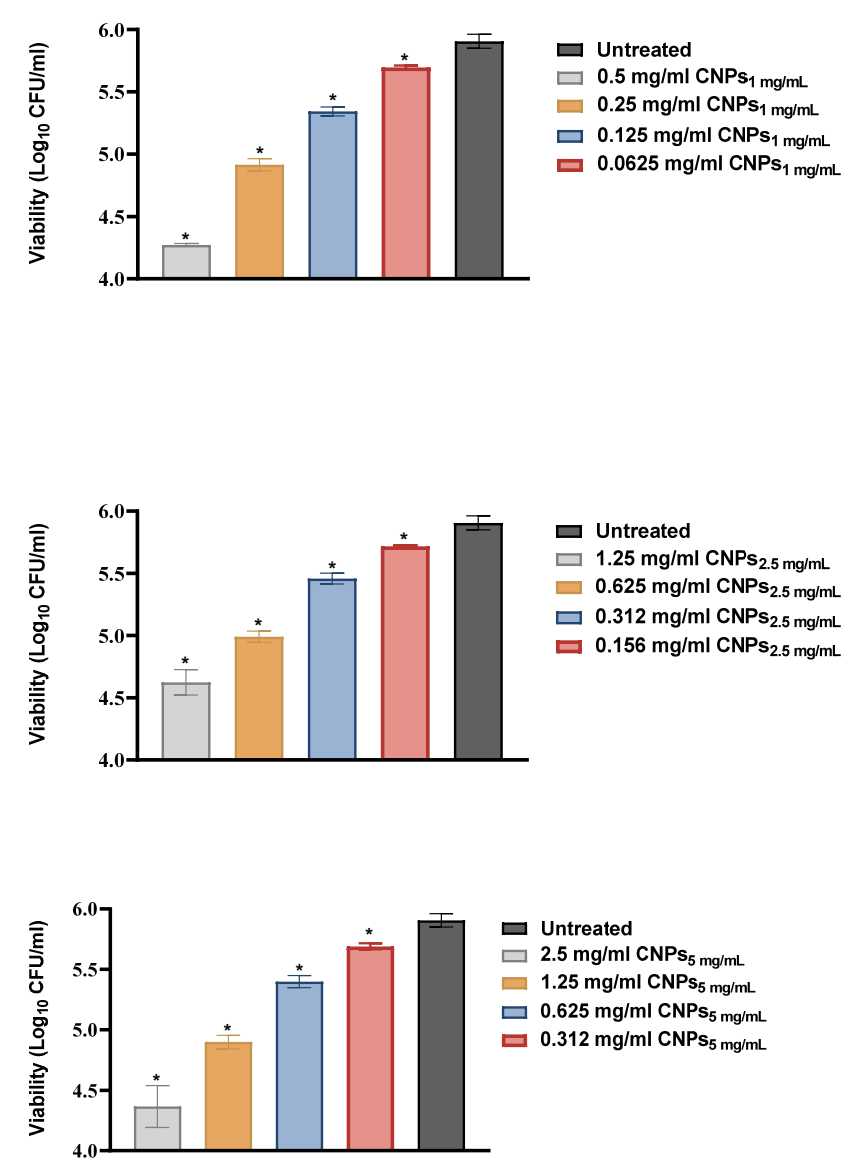

\section{TIGR4- $\Delta$ cps}
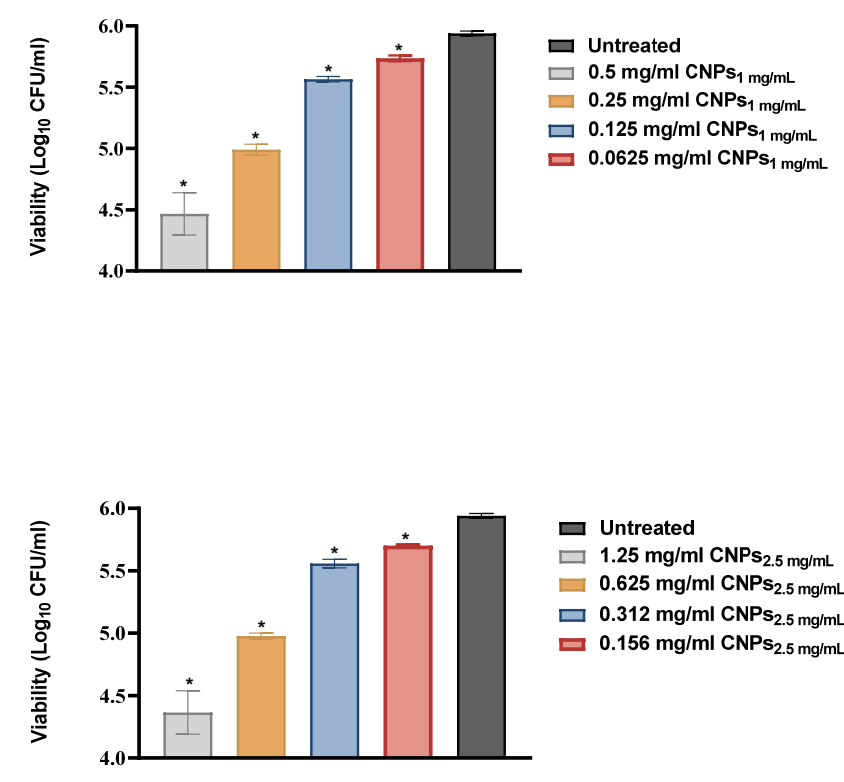

$\square$ Untreated

$\square 1.25 \mathrm{mg} / \mathrm{ml} \mathrm{CNPs} 2.5 \mathrm{mg} / \mathrm{mL}$

$0.625 \mathrm{mg} / \mathrm{ml} \mathrm{CNPs} \mathbf{2}_{2.5} \mathrm{mg} / \mathrm{mL}$

$\square 0.312 \mathrm{mg} / \mathrm{ml} \mathrm{CNPs} 2.5 \mathrm{mg} / \mathrm{mL}$

$0.156 \mathrm{mg} / \mathrm{ml} \mathrm{CNPs} 2.5 \mathrm{mg} / \mathrm{mL}$

Figure 5. Effect of CNPs on bacterial killing. S. pneumoniae TIGR4 and TIGR4- $\Delta$ cps were co-incubated with CNPs for $5 \mathrm{~h}$, then serially diluted and plated. The number of colonies (CFU) were counted after overnight incubation. The data is presented as the mean \pm SD of triplicate for one representative experiment. ${ }^{*} p<0.05$ in ANOVA test relative to viability of untreated bacteria.

\subsection{The CNPs Reduced Pneumococcal Hemolysis Activity}

The effect of CNPs on the hemolysis activity of bacterial culture supernatants was investigated using a hemolysis test. As observed in Figure 6, the CNPs induced a significant $(p<0.05)$, concentration-dependent reduction in the hemolytic activity of supernatant from TIGR4 and its capsule mutant. This suggests that CNPs inhibit bacterially induced hemolysis from pneumococcal supernatant. This is likely due to pneumolysin; however, this cannot be determined solely by the results of this study. 


\section{TIGR4}
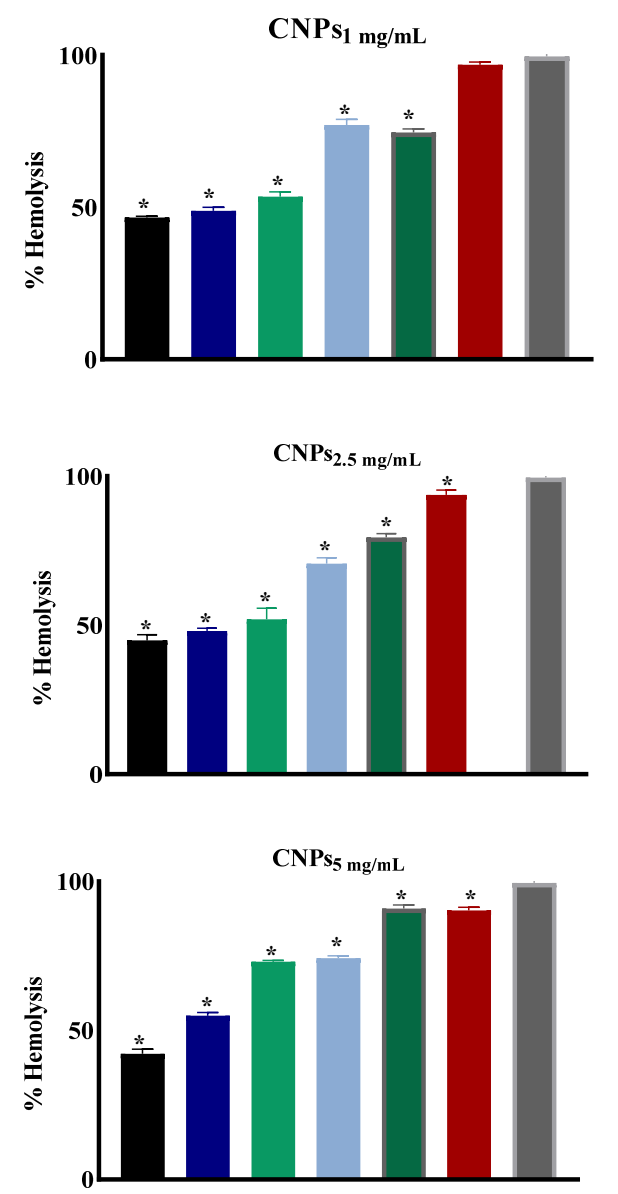

\section{$\Delta$ Cps.TIGR4}
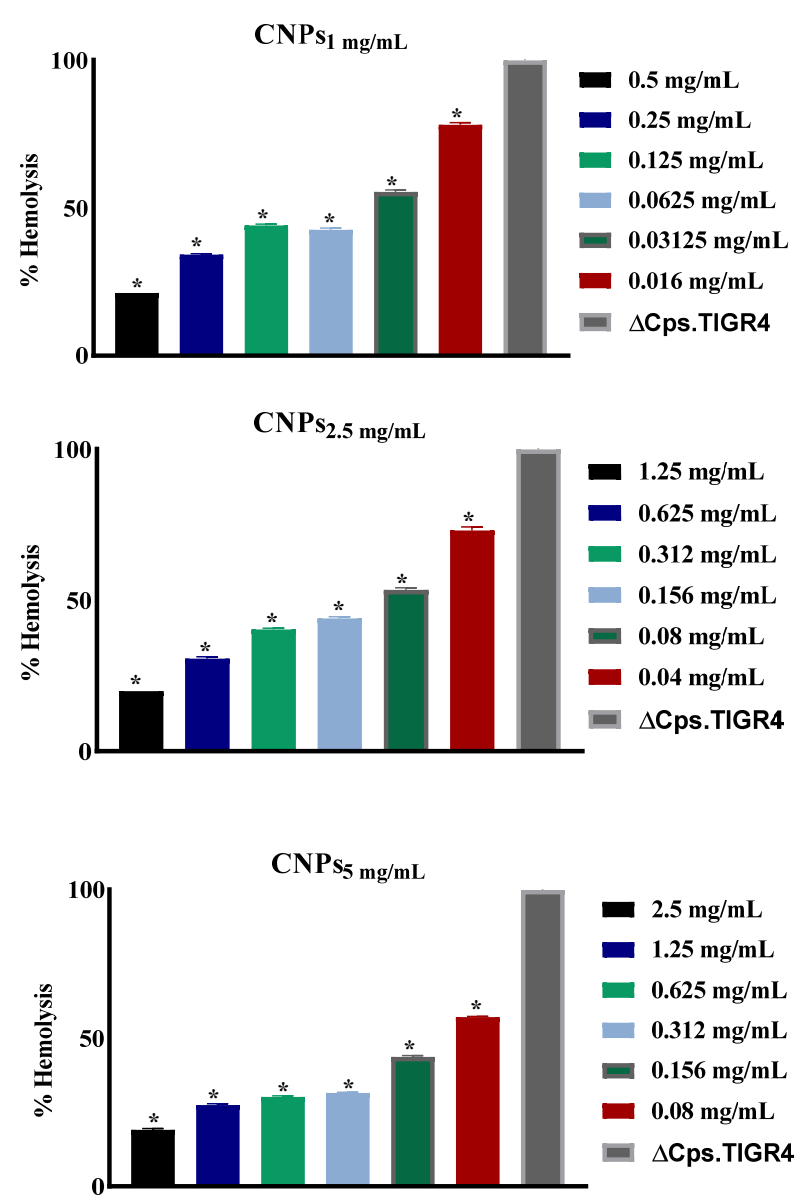

Figure 6. Effect of CNPs on the hemolytic activity of pneumococcal isolates. S. pneumonia TIGR4 and TIGR4- $\Delta$ cps were co-incubated with CNPs for $5 \mathrm{~h}$, bacterial supernatant was incubated with blood for $30 \mathrm{~min}$, then absorbance was measured after centrifugation. The data is presented as the mean $\pm \mathrm{SD}$ of triplicate experiments. ${ }^{*} p<0.05$ in ANVOA test relative to hemolysis control of untreated bacterial supernatant.

\subsection{Evaluation of CNPS Cytotoxicity}

In order to verify the safe use of CNPs as antimicrobials in humans, the cytotoxicity of synthesized NPs was studied on the A549 lung carcinoma host cell using the alamarBlue assay. The viability of cells exposed to different concentrations of CNPs is illustrated in Figure 7. A significant reduction in A549 cell viability was observed when treated for 24 hrs with $2.5 \mathrm{mg} / \mathrm{mL}$ concentrations of CNPs $5 \mathrm{mg} / \mathrm{mL}$ (Figure 7A). The CNPs $2.5 \mathrm{mg} / \mathrm{mL}$ and $\mathrm{CNPs}_{1 \mathrm{mg}} / \mathrm{mL}$ showed a less pronounced reduction in cell viability $(30 \%$ and $23.8 \%$, respectively at $1.25 \mathrm{mg} / \mathrm{mL}$ and $0.5 \mathrm{mg} / \mathrm{mL}$ concentrations; Figure $7 \mathrm{~B}, \mathrm{C}$ ) and no cell death was observed at lower concentrations that still had antibacterial activity. Notably, synthesized NPs from CNPs1 mg/mL were the least cytotoxic nanoparticles at the MIC 90 concentration utilized. 
A

$\mathrm{CNPs}_{5} \mathrm{mg} / \mathrm{mL}$

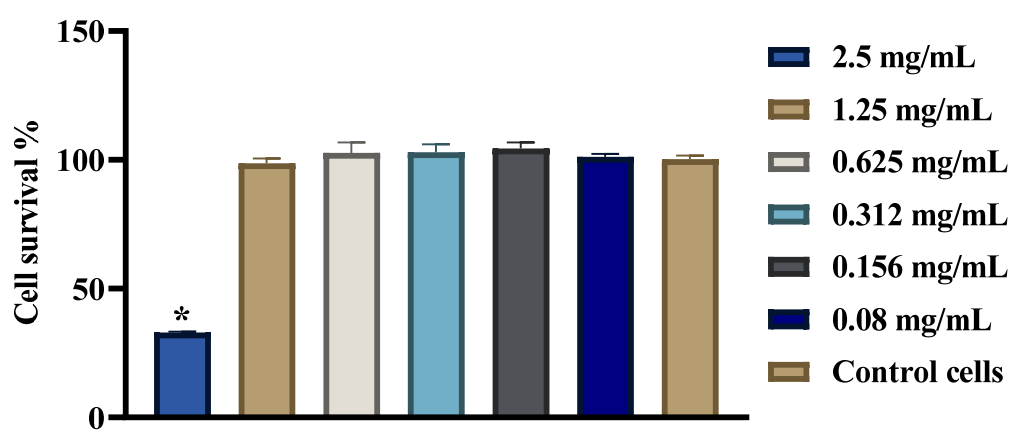

B

$\mathrm{CNPs}_{2.5} \mathrm{mg} / \mathrm{mL}$

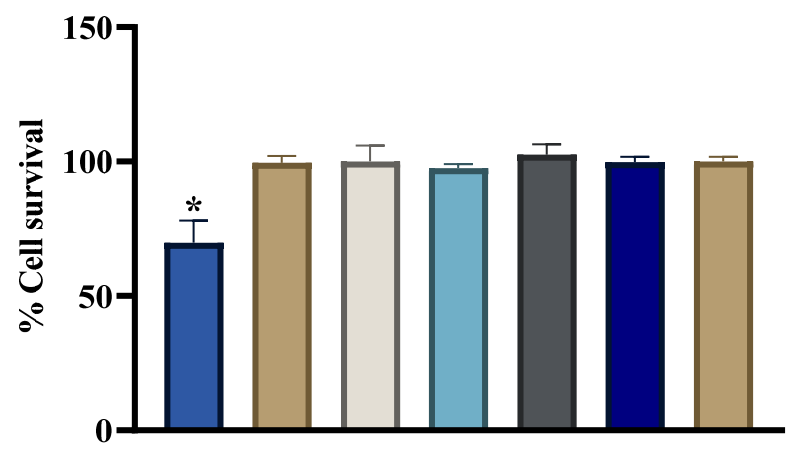

$1.25 \mathrm{mg} / \mathrm{mL}$

$0.625 \mathrm{mg} / \mathrm{mL}$

$0.312 \mathrm{mg} / \mathrm{mL}$

$0.156 \mathrm{mg} / \mathrm{mL}$

$0.08 \mathrm{mg} / \mathrm{mL}$

$0.04 \mathrm{mg} / \mathrm{mL}$

Control cells

C

$\mathrm{CNPs}_{1 \mathrm{mg} / \mathrm{mL}}$

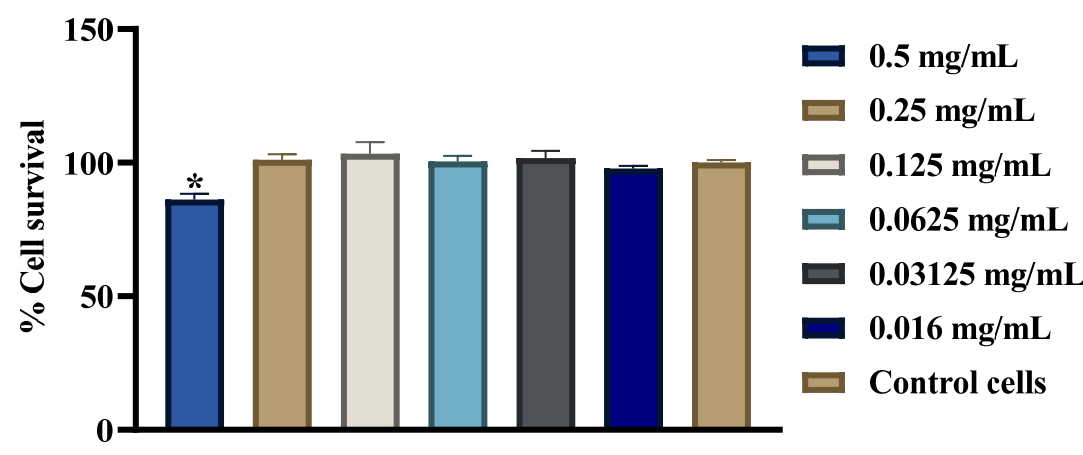

Figure 7. Effects of CNPs on A549 cell viability. Cells were left untreated or treated with different concentrations of $\mathrm{CNPs}_{5} \mathrm{mg} / \mathrm{mL}$ (A), $\mathrm{CNPs}_{2.5} \mathrm{mg} / \mathrm{mL}$ (B) and CNPs $1 \mathrm{mg} / \mathrm{mL}$ (C). Cell viability was assessed using alamarBlue assay. The data is presented as the mean $\pm \mathrm{SD}$ of triplicate experiments. ${ }^{*} p<0.05$ in Student's $t$-test relative to control untreated cells.

\section{Discussion}

The emergence of pneumococcal infections caused by multidrug-resistant strains represents a major global public health concern. In previous studies [12-18], Cs-based NPs have demonstrated a wide spectrum of antimicrobial properties. However, according to our knowledge, the current study is the first to highlight the potential use of CNPs against the clinical S. pneumoniae isolate TIGR4 and its capsule-negative mutant.

In the current investigation, we found that as the concentration of Chitosan was increased, the particle size and zeta potential of formed CNPs increased correspondingly in accordance with previous reports $[12,16,18,25]$. In the current study, we did not succeed in culturing pneumococcal isolates under acidic $\mathrm{pH}$, which would provide optimal 
protonation of the chitin of the CNPs. Instead, the antimicrobial effect of CNPs was investigated under neutral $\mathrm{pH}$. Using a standardized broth dilution assay, the $\mathrm{MIC}_{90}$ of $\mathrm{CNPs}_{1} \mathrm{mg} / \mathrm{mL}, \mathrm{CNPs}_{2.5 \mathrm{mg} / \mathrm{mL} \text {, and CNPs }} \mathrm{mg} / \mathrm{mL}$ were found to be $0.5 \mathrm{mg} / \mathrm{mL}, 1.25 \mathrm{mg} / \mathrm{mL}$, and $2.5 \mathrm{mg} / \mathrm{mL}$, respectively. Cs anti-bacterial action is $\mathrm{pH}$-dependent, and it is soluble in acidic environments, and thus, becomes polycationic when the $\mathrm{pH}$ is below the molecule's pKa $(6.3-6.5)[8,12]$. Here, the inclusion of the CNPs in the assay media at these concentrations used shifted the $\mathrm{pH}$ to be slightly more acidic (approximately $\mathrm{pH}=6$ ), which is more optimal in providing protonation of the Chitosan. Several studies have reported antimicrobial activities of Cs and CNPs only at acidic $\mathrm{pH}$ [8,12]; however, this has not been proved to be strictly consistent. At lower $\mathrm{pHs}$, Chitosan has stronger inhibitory activity that is reduced as $\mathrm{pH}$ rises. This explains the higher MIC90 results observed in our study as the $\mathrm{pH}$ of the media used for the assays was not acidic, resulting in the presence of a significant number of uncharged amine groups and low solubility of Cs at these conditions. There are several proposed mechanisms of antimicrobial action of Cs $[12,26]$. One mechanism depends on electrostatic interaction between negatively charged microbial membrane and positively charged Cs resulting in leakage of intracellular components. At $\mathrm{pH}=7$, the free Cs and outer Cs in prepared NPs are presumed to be neutral; however, the Cs charge within the NPs might be retained. Such retained positive charge might contribute to the antibacterial activity exhibited by CNPs synthesized in our study against pneumococcal isolates and other reports against Streptococcus mutans [17] and E. coli [27]. This might occur via the interaction of CNPs with negatively charged components, including peptidoglycan and teichoic acid in the cell walls of gram-positive bacteria. Another possible mechanism is the capacity of Cs to chelate metal ions in bacteria which has been reported for both acidic and neutral conditions $[7,8]$. Of note, Cs-mediated chelation of the metal ions is more effective at higher $\mathrm{pH}[8]$.

Capsular polysaccharide plays a significant role in pneumococcal survival to protect the bacteria from the host inflammation $[27,28]$. It contributes to pneumococcal virulence and is used for serotypes classification [29-31]. In our study, TIGR4 lacking capsular polysaccharide was found to be equally susceptible to the effect of CNPs as the wild-type strain. This finding suggests that the capsule material is not the target for CNPs and also that capsule does not interfere with CNP-induced anti-pneumococcal activity. It also might suggest that the contribution of other bacterial compartments, such as the cell wall or bacterial cell membrane in CNPs mediated anti-pneumococcal activity. The mechanism of CNPs bactericidal activity and specific targets will be addressed in a separate study.

Besides their direct bactericidal activities, the CNPs used here also displayed inhibition of hemolysis induced by pneumococci. We were able to demonstrate that the CNPs resulted in a concentration-dependent inhibition of pneumococcal hemolysis induced by TIGR4 and its capsule-negative mutant. This implies a potential anti-virulence effect of CNPs toward S. pneumoniae; however, the exact mechanism of the observed hemolysis attenuation is unknown from current findings. As pneumolysin is a known cholesterol-dependent toxin with hemolytic ability, it is tempting to speculate that CNPs may directly interact with pneumolysin and interfere with its function.

Finally, to provide evidence that CNPs may potentially be used safely to treat infections, the cytotoxicity of the CNPs prepared in this study was investigated against A459 lung carcinoma cells. Higher concentrations of $\mathrm{CNPs}_{5} \mathrm{mg} / \mathrm{mL}$ were found to be markedly cytotoxic, but this was not observed for $\mathrm{CNPs}_{2.5} \mathrm{mg} / \mathrm{mL}$ and $\mathrm{CNPs}_{1} \mathrm{mg} / \mathrm{mL}$, suggesting that these formulations would be more favorable to use as therapeutics. Such cytotoxicity of CNPs prepared from higher concentrations of Cs is expected owing to their high zeta potential. These results corroborate other studies in which the CNPs cytotoxicity was evaluated on other cell lines such as HeLa cells [18].

\section{Conclusions}

In summary, the findings of this study reveal that the formulated CNPs produced capsule-independent anti-pneumococcal activity. NPs fabricated from lower concentrations 
of Cs were cytocompatible. In addition, the CNPs attenuate pneumococcal hemolysis in a concentration-dependent manner. As a result, the findings reported here suggest the potential of using nanochitosan as a future antimicrobial and anti-virulence strategy against S. pneumoniae.

Author Contributions: F.Y.A. and F.S.A.: Conceptualization, design of study, acquisition of data, validation, and writing original draft preparation. E.E.T., H.A., A.B., B.A. and A.A.-B.: Acquisition of data, analysis of data, visualization, and interpretation of data. A.P.H. and I.A.: Resources, visualization, and interpretation of data, writing-reviewing, and editing. All authors have read and agreed to the published version of the manuscript.

Funding: This research project was supported by Researchers Supporting Project number (RSP2021/340), King Saud University, Riyadh, Saudi Arabia.

Conflicts of Interest: The authors declare no conflict of interest.

\section{References}

1. Bogaert, D.; De Groot, R.; Hermans, P.W. Streptococcus pneumoniae colonisation: The key to pneumococcal disease. Lancet Infect. Dis. 2004, 4, 144-154. [CrossRef]

2. Appelbaum, P.C. Resistance among Streptococcus pneumoniae: Implications for drug selection. Clin. Infect. Dis. 2002, 34, 1613-1620. [CrossRef]

3. WHO. Antimicrobial Resistance: Global Report on Surveillance 2014; Antimicrobial Resistance Global Surveillance Report; World Health Organization: Geneva, Switzerland, 2014.

4. Eleraky, N.E.; Allam, A.; Hassan, S.B.; Omar, M.M. Nanomedicine fight against antibacterial resistance: An overview of the recent pharmaceutical innovations. Pharmaceutics 2020, 12, 142. [CrossRef] [PubMed]

5. Panja, S.; Bharti, R.; Dey, G.; Lynd, N.A.; Chattopadhyay, S. Coordination-assisted self-assembled polypeptide nanogels to selectively combat bacterial infection. ACS Appl. Mater. Interfaces 2019, 11, 33599-33611. [CrossRef] [PubMed]

6. Kong, M.; Chen, X.G.; Xing, K.; Park, H.J. Antimicrobial properties of chitosan and mode of action: A state of the art review. Int. J. Food Microbiol. 2010, 144, 51-63. [CrossRef] [PubMed]

7. Rabea, E.I;; Badawy, M.E.; Stevens, C.V.; Smagghe, G.; Steurbaut, W. Chitosan as antimicrobial agent: Applications and mode of action. Biomacromolecules 2003, 4, 1457-1465. [CrossRef]

8. Chandrasekaran, M.; Kim, K.D.; Chun, S.C. Antibacterial activity of chitosan nanoparticles: A review. Processes 2020, 8, 1173. [CrossRef]

9. Tikhonov, V.E.; Stepnova, E.A.; Babak, V.G.; Yamskov, I.A.; Palma-Guerrero, J.; Jansson, H.B.; Lopez-Llorca, L.V.; Salinas, J.; Gerasimenko, D.V.; Avdienko, I.D.; et al. Bactericidal and antifungal activities of a low molecular weight chitosan and its N-/2(3)-(dodec-2-enyl)succinoyl/-derivatives. Carbohydr. Polym. 2006, 64, 66-72. [CrossRef]

10. U.S. Food and Drug Administration. Shrimp-Derived Chitosan GRAS Notification. 2012. Available online: www.accessdata.fda. gov/scripts/fcn/gras_notices/GRN000443pdf (accessed on 10 August 2021).

11. Goy, R.C.; Britto, D.D.; Assis, O.B. A Review of the Antimicrobial Activity of Chitosan. Ciênc. Tecnol. 2009, 19, 241-247. [CrossRef]

12. Qi, L.; Xu, Z.; Jiang, X.; Hu, C.; Zou, X. Preparation and antibacterial activity of chitosan nanoparticles. Carbohydr. Res. 2004, 339, 2693-2700. [CrossRef]

13. de Campos, A.M.; Diebold, Y.; Carvalho, E.L.; Sánchez, A.; Alonso, M.J. Chitosan nanoparticles as new ocular drug delivery systems: In vitro stability, in vivo fate, and cellular toxicity. Pharm. Res. 2004, 21, 803-810. [CrossRef]

14. Divya, K.; Vijayan, S.; George, T.K.; Jisha, M.S. Antimicrobial properties of chitosan nanoparticles: Mode of action and factors affecting activity. Fibers Polym. 2017, 18, 221-230. [CrossRef]

15. Wardani, G.; Sudjarwo, S.A. In vitro Antibacterial Activity of Chitosan Nanoparticles against Mycobacterium tuberculosis. Pharmacogn. J. 2018, 10, 162-166. [CrossRef]

16. Aleanizy, F.S.; Alqahtani, F.Y.; Shazly, G.; Alfaraj, R.; Alsarra, I.; Alshamsan, A.; Abdulhady, H.G. Measurement and evaluation of the effects of $\mathrm{pH}$ gradients on the antimicrobial and antivirulence activities of chitosan nanoparticles in Pseudomonas aeruginosa. Saudi Pharm. J. 2018, 26, 79-83. [CrossRef] [PubMed]

17. Chavez de Paz, L.E.; Resin, A.; Howard, K.A.; Sutherland, D.S.; Wejse, P.L. Antimicrobial effect of chitosan nanoparticles on streptococcus mutans biofilms. Appl. Environ. Microbiol. 2011, 77, 3892-3895. [CrossRef]

18. Alqahtani, F.; Aleanizy, F.; El Tahir, E.; Alhabib, H.; Alsaif, R.; Shazly, G.; AlQahtani, H.; Alsarra, I.; Mahdavi, J. Antibacterial Activity of Chitosan Nanoparticles Against Pathogenic N. gonorrhoea. Int. J. Nanomed. 2020, 15, 7877-7887. [CrossRef]

19. Calvo, P.; Remuñan-López, C.; Vila-Jato, J.L.; Alonso, M.J. Chitosan and chitosan/ethylene oxide-propylene oxide block copolymer nanoparticles as novel carriers for proteins and vaccines. Pharm. Res. 1997, 14, 1431-1436. [CrossRef]

20. Tettelin, H.; Nelson, K.E.; Paulsen, I.T.; Eisen, J.A.; Read, T.D.; Peterson, S.; Heidelberg, J.; DeBoy, R.T.; Haft, D.H.; Dodson, R.J.; et al. Complete genome sequence of a virulent isolate of Streptococcus pneumoniae. Science 2001, 293, 498-506. [CrossRef] 
21. Thamadilok, S.; Roche-Håkansson, H.; Håkansson, A.P.; Ruhl, S. Absence of capsule reveals glycan-mediated binding and recognition of salivary mucin MUC7 by Streptococcus pneumoniae. Mol. Oral Microbiol. 2016, 31, 175-188. [CrossRef]

22. CLSI. Performance Standards for Antimicrobial Susceptibility Testing; CLSI Supplement M100; Weinstein, M.P., Ed.; Clinical and Laboratory Standards Institute: Wayne, PA, USA, 2020.

23. Yang, Y.; Lin, J.; Harrington, A.; Cornilescu, G.; Lau, G.W.; Tal-Gan, Y. Designing cyclic competence-stimulating peptide (CSP) analogs with pan-group quorum-sensing inhibition activity in Streptococcus pneumoniae. Proc. Natl. Acad. Sci. USA 2020, 117, 1689-1699. [CrossRef] [PubMed]

24. AbuMousa, R.A.; Baig, U.; Gondal, M.A.; AlSalhi, M.S.; Alqahtani, F.Y.; Akhtar, S.; Aleanizy, F.S.; Dastageer, M.A. Photo-catalytic killing of HeLa cancer cells using facile synthesized pure and Ag loaded WO3 nanoparticles. Sci. Rep. 2018, 8, 15224. [CrossRef]

25. Ing, L.Y.; Zin, N.M.; Sarwar, A.; Katas, H. Antifungal activity of chitosan nanoparticles and correlation with their physical properties. Int. J. Biomater. 2012, 2012, 632698. [CrossRef]

26. Jeon, S.J.; Oh, M.; Yeo, W.S.; Galvao, K.N.; Jeong, K.C. Underlying mechanism of antimicrobial activity of chitosan microparticles and implications for the treatment of infectious diseases. PLoS ONE 2014, 9, e92723. [CrossRef] [PubMed]

27. Magee, A.D.; Yother, J. Requirement for capsule in colonization by Streptococcus pneumoniae. Infect. Immun. 2001, 69, 3755-3761. [CrossRef]

28. Sanders, M.E.; Norcross, E.W.; Robertson, Z.M.; Moore, Q.C.; Fratkin, J.; Marquart, M.E. The Streptococcus pneumoniae capsule is required for full virulence in pneumococcal endophthalmitis. Invest. Ophthalmol. Vis. Sci. 2011, 52, 865-872. [CrossRef] [PubMed]

29. Hyams, C.; Camberlein, E.; Cohen, J.M.; Bax, K.; Brown, J.S. The Streptococcus pneumoniae capsule inhibits complement activity and neutrophil phagocytosis by multiple mechanisms. Infect. Immun. 2010, 78, 704-715. [CrossRef]

30. Hathaway, L.J.; Brugger, S.D.; Morand, B.; Bangert, M.; Rotzetter, J.U.; Hauser, C.; Graber, W.A.; Gore, S.; Kadioglu, A.; Mühlemann, K. Capsule type of Streptococcus pneumoniae determines growth phenotype. PLoS Pathog. 2012, 8, e1002574. [CrossRef] [PubMed]

31. Wyres, K.L.; Lambertsen, L.M.; Croucher, N.J.; McGee, L.; Von Gottberg, A.; Liñares, J.; Jacobs, M.R.; Kristinsson, K.G.; Beall, B.W.; Klugman, K.P.; et al. Pneumococcal capsular switching: A historical perspective. J. Infect. Dis. 2013, 207, 439-449. [CrossRef] [PubMed] 